\title{
GEOINFORMATION SYSTEMS IN THE FIELD OF AGRICULTURAL
}

\section{LAND USE}

G.I. Sharyi, D. in Economics, Professor, Department of Highways, Geodesy, Land Management and Rural Buildings

S.V. Nesterenko, Candidate of Technical Sciences (Ph. D.), Associate Professor of the Department of Highways, Geodesy, Land Management and Rural Buildings

D.S. Gamernyk, student

National university "Yuri Kondratyuk Poltava polytechnic»

V.V. Tymoshevskyi, Candidate of Economic Sciences (Ph.D.), Associate

Professor of the Department of Road design, Geodesy and Land Management

Kharkiv National Highway University

E-mail: NesterenkoS2208@gmail.com

\section{ABSTRACT}

Agribusiness conditions in Ukraine are changing. Agricultural enterprises are actively restructured, change owners, attract investors and crisis managers. Management technologies that are currently used by most Ukrainian agricultural enterprises do not allow effective management decisions and create development plans that require objective and expeditious asset valuation, analytically sound performance data. This problem can be solved by creating a unified agribusiness management system which is based on advanced analysis methods and modern information technologies.

The necessity to create a database of the land bank of enterprises with the ability to export information to the corporate system of enterprise management has been proved. Taking into account a number of criteria such as complexity, functionality and correlation price and quality, the following solutions were selected that enabled the creation of a flexible, complete and versatile agribusiness management system with the ability to modify it depending on changing needs. It is suggested to pay additional attention to the developers and to develop in each direction a software product aimed at development in the broadest sense of the 
production and macroeconomic social phenomenon. It is not just a land bank management but a land development, and it should form a geoinformation characteristic of the spatial basis by section, by legal status and by legal entities. The aforementioned analysis will form a spatial picture of basic lands, natural and economic assessment, environmental sustainability (buffering), toxicity and potential natural and economic yield.

The introduction of modern technologies increases the control of the assets of companies, the transparency of processes and information management, reduces the risks of doing business been proved.

Keywords: information systems, agricultural production, management decisions, land resources.

\section{INTRODUCTION}

The success of agrarian enterprises occupying a leading position in the market is largely due to the efficiency and timeliness of managerial decisions, which are based not only on the personal experience of managers, but also on the ability to obtain timely, accurate and complete data on companies' land resources. In modern agriculture, the complex systems of land asset management, agricultural technology management and monitoring systems are used to obtain and process information, but modern software products have drawbacks due to the fact that programmers do not know the features and specifics of land relations and the production technology, and especially poorly take into account biological, geobotanical, natural-climatic, soil differences, the specifics of edaphotope in production and even worse take into account the social and institutional aspects of a lease.

\section{ANALYSIS OF RECENT RESEARCH AND PUBLICATIONS}

Researchers in the field of information systems have been engaged in by foreign researchers, in particular R. Bennett, J. Williamson, D. Wallace, K. Dayt, S. Enemark, T. Parsons, P. Chen. The problems of organization of land use, the improvement of land-information systems of land use and protection in Ukraine are 
devoted to the works of A.S. Bordiuzhi, A.P. Verveik, A.Ya. Sokhnych, M.H. Stupen, A.M. Tretiak, O. Kovaliv, M. H. Maltsev, O. Dorosh, H. Hutsuliak, V. Budzhiak and others [1-3]. Taking into account the significant scientific advances in this field, the question of creating an effective land management system with the help of information systems has become relevant today.

The purpose of the research is to substantiate the need to create an information system in the field of agricultural land use on the basis of geoinformation systems of the land bank of agricultural enterprises with the possibility of exporting information to the corporate enterprise management system (holding). The problem should be solved by methods of analysis and using modern information technologies.

\section{RESULTS AND DISCUSSION}

The launch of a new management technology in agrarian enterprise is preceded by a process of analyzing the types of activity of structural units, identifying the existing mechanisms for solving problems and possible ways to improve them. There is a need to create a database of a land bank of enterprises, including subsidiaries with the ability to export information to the corporate enterprise management system. Based on criteria such as complexity, functionality and the correlation between price and quality, the solutions are selected that allow, with a minimum number of software products to create a flexible, complete and versatile agribusiness management system with the ability to configure it depending on changing needs (Fig. 1).

The management of land resources of the enterprise involves actions aimed at the most efficient and rational use of lands as a spatial (production) base, the main means of production, the subject of labor, on the development of land relations and spatial guarantees and increase the land bank.

The approaches to management architecture are: multifunctional solution in the form of WEB or mobile applications with a single authorization; functional module is the process of agribusiness management; full integration with IC accounting system; integration with solutions that accumulate the necessary data; system data transfer and other software solutions [4]. 


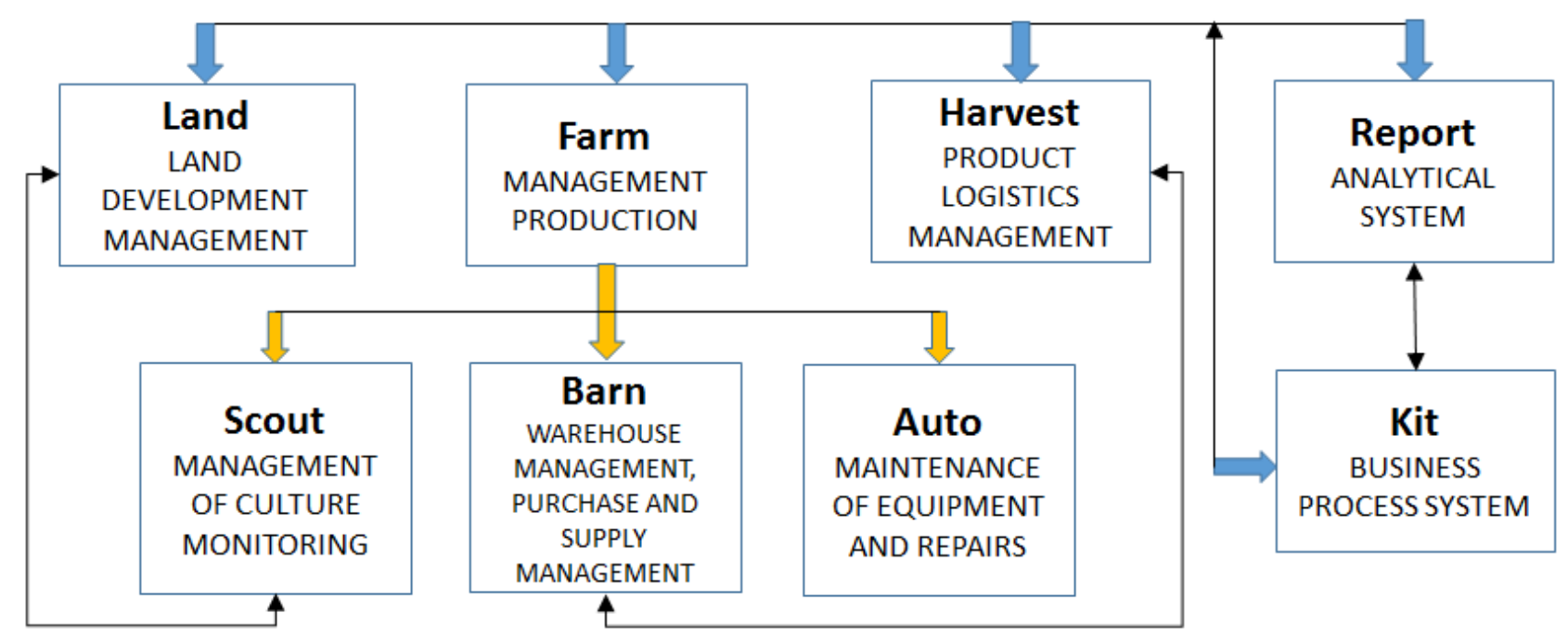

Fig. 1. Architecture of management decisions

To automatization the process of management and to improve information security, the efficiency and interconnection of land, legal, economic and industrial service of large enterprises, it is possible only by the complex implementation of the information system of land management, bringing all processes to uniform regulations, and documents to uniform standards. [3]. Otherwise, there are different economic and social problems that can result in significant losses for the agricultural companies. A geoinformation system must be formed of several subsystems. For example, the subsystem for assessing the legal status of individual land plots: : agricultural lands by legal status and legal entities; arable land in arrays of agricultural companies (plots from mutual fund for rent, plots for emphitheism, leased for 30 years or more); owners - landlords working in the enterprise (landlords family members working in the enterprise; landlords - pensioners living in villages or communities; landlords - pensioners living outside communities; landlords of ablebodied people living in the village but not working in the enterprise; landlords of heirs living in cities; units of extinct heritage; shares - plots of communal property for rent); state arable land for rent (arable land adjacent to agricultural firm fields with similar division). Leasing is a major aspect of the economic circulation of land and the formation of the spatial basis of agricultural production. And it is necessary that 
the software product to be developed, especially in the lease, be geared towards land development and the optimal land use according to production needs.

The concept of creating an automated management system is: a unified business management information system, the work of services at all levels of management, the automated flexible business processes, the task management for professionals, message systems, tools for work and decision making, the automated workflow, the system of deep analytical reporting based on risk management, online business event mode, simple intuitive interface [5].

The geoinformation system should cover all areas of the management process of agrobusiness, forming a single functional module of the management decision architecture, and its users should be able to synchronize their processes. For this purpose, all available mapping material - maps of village councils, exchange files, scanned or electronic field maps, as well as an open cadastral map of Ukraine are reduced to a single electronic card of the company. Registers of land lease agreements are systematized, imported into a single database and linked to a specially created electronic map. The electronic map objects are displayed in certain colors according to the selected criteria: the legal status of the lease agreements is registered / unregistered sites, unclaimed etc; the lease term for the completion of the land plots up to 6 months, from 6 to 12 months, more than a year, etc.

At the same time, for full integration with the IS accounting system the data entry forms and report templates are created, templates are tied to leases, acts and other documents, and service regulations and instructions are described. A separate issue is setting up permissions to map information and databases. Within the framework of projects, each client has an individual system of access to information differentiation of access according to specific divisions or village councils, the possibility of limiting user actions (viewing, printing, editing, copying), etc.

When exchanging land rights in certain arrays, it is necessary to take into account the natural bonus (score-hectare) with the purpose of forming integral arrays, creating an electronic map of fields and further forming a cadastral accounting database. This allows you to resolve the issue of controlling the movement of land as 
an object of property. And in conjunction with crop rotation data, soil condition is making land monitoring one of the most important productive resources. By visualizing the field map and the company cadastral map, at this stage two more land features are added - received in exchange and transmitted in exchange. The management of the enterprise has the opportunity to control the process of exchange in terms of logistics and the correspondence of the area of the received sections of the area transferred. The subsystem of a geoinformation system of the field contour monitoring is also launched in line with changes in the land bank [6].

It is also necessary to form a subsystem of lease relations, the analysis should be performed on the lease term, where the leases with less than 2 years are in the risk zone and less than 1 year in the absolute risk zone. The specified information is necessary for the individual and perspectives work with the social environment of actual landlords and aims at spatial guarantees of the land use, the perspectives for development and competitive activity. Similarly, it is necessary to study the database of third-party owners and users within spatial accessibility (community, district) in order to work with perspective landlords in the future: potentially rentable units for the rent (third-party landlords), a special analysis of units in the actual exchange use of agricultural enterprises. The following subsystem analyzes: agricultural lands by qualitative characteristics - soil maps (agro-groups), with a certain bonus (in points), soil maps by the reaction of soil solution (in dynamics by years); availability of microelements (potassium, phosphorus); a dynamic nitrogen supply card; characteristics of edaphotope (earthworms, $t /$ ha, crop residues (organic impurities), $t$ / ha, humus, $\mathrm{t}$ / ha); moisture content in the meter layer in the dynamics (by years); depth of groundwater; moisture reserve in the upper two genetic horizons $(0-20 \mathrm{~cm})$. It is also necessary to analyze the surface characteristics (equal, $0-1^{0}, 1-2^{0}, 2-3^{0}, 3-5^{0}$; $5^{0}$ and above); soil condition indicators (herbicide aftereffect); the presence of biological threats and factors. The following subsystem analyzes:productivity in dynamics by years; profitability in dynamics (production); economic valuation of rent 1 ha (yield $\times$ lease term); economic valuation of 1 ha (for the period of capitalization). The performance and efficiency of agribusiness management depends 
not only on the availability of reliable information on the area and condition of the fields, but also on the promptness of obtaining such information. Another subsystem includes a technological field map with field history and site-specific binding needs to be optimized using the same software, and the information is automatically generated in real time. Thanks to satellite monitoring, all agricultural machinery is controlled: up to square meters it is possible to determine the area processed for work shift; whether the field processing is performed correctly; calculate fuel costs; to find out the exact position of the technique now, etc.

As a result, we have a conditional scheme "field contours - terrain - technics". The integration takes place with the solutions that accumulate the required data with the accounting system IP and data transmission of the system.

As practice shows, such projects are implemented within 3-6 months, and the obtained results fully offset the costs of the company. Taking into account the uncertainty in the context of domestic legislation, the situation in the country's economy, the introduction of information systems for a land management of agroholding will be relevant for a long time.

The aforementioned analysis will form a spatial picture of basic lands, the natural and economic assessment, the environmental sustainability (buffering), and potential natural and economic yields. It will be possible to generate and assess risks in agriculture and in the land development by targeting the land development to arrays with positive economic characteristics, concentrating efforts on consolidation of lands, the formation of a rational land uses, the decrease of land and the increase of land profitability.

The economic valuation of land by its own indicators of income and expenditure will indicate the most highly profitable and low income areas that require rethinking and changing the agro-development, directions and intensity.

The unified business management information system - a picture of direct and transaction (lease) costs will indicate the potential possibility and profitable ability of arable farming in specific enterprises. In-depth self-analysis of the activity will allow to see a clear picture of the recoupment of direct (reduced) costs and the real price of 
the possible redemption of land in the ownership of enterprises. For the comprehensive implementation of the management information system, it is necessary to take into account the presence of farm yards, as farm yards are an integral part of the production space.

Namely, farm yards outside settlements (farm yards outside in permanent use, farm yards outside rent), farm yards within settlements (farm yards within settlements in permanent use, farm yards in farms are redeemed and are on balance, farm yards are within lease limits).

A great importance for holistic development, of agribusiness management, taking into account favorable location, convenient logistics, have industrial land plots of elevators, sugar plants, oil and fat factories, meat processing plants, dairies, bakeries, feed mill plants, electricity holding companies, plants on bioethanol production, seed plants included into the holding structure, agro corporations, or even medium-sized agribusinesses. Namely: industrial plots outside of leased settlements; industrial areas outside settlements in permanent use; industrial plots outside settlements are planned for purchase; industrial areas outside the settlements were bought out and put on the balance. The architecture of management decisions provides for optimization of cargo flows and commodity production zones, which contributes to the solution of transport problems and, consequently, to the formation of quasi-rents, especially for the large agricultural producers. Economic analysis of the production base on land under farms and industrial enterprises will give impetus to the land development of each plot in order to improve its valuation characteristics, liquidity of objects, holistic property complexes, optimization of land payments to the budget and their significant reduction.

It is necessary to form a program of the land and industrial development, knowing that the costs of land consolidation, rationalization, configuration, transport accessibility, the reasonable land use will make the land more expensive asset and pay off in each case. 


\section{CONCLUSIONS}

Today, innovative technologies are an indispensable component of any industry, they significantly increase the production productivity of enterprises. Automation of agribusiness management system has become a necessity.

In addition, the introduction of modern technologies increases the control of company assets, the transparency of processes and information management, reduces the risks of doing business, both in the short and long term.

It is proposed to further develop software aimed at the development in a production sphere, in the sphere of land relations, and ways to optimize the land use and and the expansion of sites. It is not easy to manage an existing land bank, but to progressively shape the land development, forming a geoinformation characteristic of the spatial basis in development.

The search for rationality points not so much to the reduction of the land use, but to the potential for additional competitive negative externalities and risks in the abandonment of farm yards and reserve areas, which can be the basis of intensification, eco-energy, irrigation lands, medicinal herbs, greenhouses, the baby food combinates, because the best agronomist in the world is a smart cyber farming.

\section{REFERENCES}

Bordiuzha A. S. 2014. Informatsiyne zabezpechennya systemy upravlinnya zbalansovanym sil's'kohospodars'kym zemlekorystuvannyam: dys. ... kand. s.-h. nauk: 08.00.06 [Information support for the system of management of balanced agricultural land use]. Instytut ahroekolohiyi i pryrodokorystuvannya NAAN. Kyiv, 234. (in Ukrainian)

Stupen' M.H. 2016. Svitovyi dosvid funktsionuvannia kadastrovykh system u konteksti ratsional'noho zemlekorystuvannya [World experience in the operation of cadastral systems in the context of rational land use] Investytsii: praktyka ta dosvid, 17: 22-26. (in Ukrainian)

Taratula R. B. 2016. Formuvannia struktury intehrovanoi zemel'noinformatsiinoi systemy [Formation of the structure of the integrated land information 
system] Zbalansovane pryrodokorystuvannia: naukovo-praktychnyy zhurnal, 4: 173177. (in Ukrainian)

Petrunia Yu. Ye., Litovchenko B. V., Pasichnyk T.O. 2015. Pryiniattia upravlins'kykh rishen' [Management Decision Making]: navch. posib. Dnipropetrovs'k, 209. (in Ukrainian)

Pro skhvalennia Kontseptsii stvorennia zahal'noderzhavnoi avtomatyzovanoi systemy «Vidkryte dovkillia»: [ On approval of the Concept of creation of the national automated system «Open Environment»: CMU Order of 7.11.2018 № 825-p. Available at: https://zakon.rada.gov.ua/laws/main/825-2018-\%D1\%80] (in Ukrainian)

Systema upravlinnya zemel'nym bankom [Land Bank Management System] Smart farming. Available at: http://smartfarming.ua/ua-upravlinnya-zemelnimbankom.

\section{Г.І. Шарий, С.В. Нестеренко, В.В. Тимошевський, Д.С. Гамерник}

\section{Геоінформаційні системи в сфері аграрного землекористування}

Анотація. Умови аграрних відносин в Україні стрімко змінюються. Аграрні підприємства активно реструктуризуються, змінюють власників, залучають додаткових інвесторів та антикризових менеджерів. Технології управління, які на сьогодні застосовують на більшості сільгосппідприємствах України, не дозволяють ефективно приймати оперативні управлінські рішення і формувати плани земельного розвитку, так як вимагають об'єктивної та оперативної оцінки земельних активів, аналітично обгрунтованих даних про потенційних і існуючих землекористувачів. Розв'язати проблему можна за рахунок створення єдиної системи управління земельними ресурсами, яка грунтується на передових методах аналізу i сучасних інформаційних технологіях. Доведена необхідність у створенні бази даних земельного банку підприємств групи 3 можливістю експорту інформації до корпоративної системи управління підприємством. Керуючись такими критеріями, як комплексність, функціональність та співвідношення ціна/якість, обрано такі 
рішення, які дозволили б за допомогою мінімальної кількості програмних продуктів створити гнучку, повноцінну та універсальну систему управління агробізнесом 3 можливістю конфігурувати іiі залежно від зміни потреб. Пропонується додатково звернути увагу розробників на те, що по кожному напрямку необхідно розробити програмний продукт, націлений на розвиток, в найширшому розумінні виробничого і макроекономічного суспільного явища, за допомогою якого можна не просто управляти земельним банком, а земельним розвитком. Програми повинні формувати геоінформаційну характеристику просторового базису в розрізі, за правовим статусом і за правосуб’єктами. Доведено, що впровадження сучасних технологій підвищує контроль активів компаній, прозорість процесів та інформаційне забезпечення менеджменту, знижує ризики ведення бізнесу.

Ключові слова: інформаційні системи, агровиробництва, управлінські рішення, земельні ресурси.

\section{Г.И. Шарый, С.В. Нестеренко, В.В. Тимошевский, Д.С. Гамерник}

Геоинформационные системы в сфере аграрного землеиспользования

Аннотация. Условия аграрных отношений в Украине стремительно меняются. Аграрные предприятия активно реструктуризируются, меняют владельцев, привлекают дополнительных инвесторов и антикризисных менеджеров. Технологии управления, которые сегодня применяют на большинстве сельхозпредприятиях Украины, не позволяют эффективно принимать оперативные управленческие решения и формировать планы земельного развития, так как требуют объективной и оперативной оценки земельных активов, аналитически обоснованных данных о потенциальных и существующих землепользователей. Решить проблему можно за счет создания единой системы управления земельными ресурсами, основанной на передовых методах анализа и современных информационных технологиях. Доказана необходимость в создании базы данных земельного банка предприятий группы с возможностью экспорта информации в корпоративной системы управления 
предприятием. Руководствуясь такими критериями, как комплексность, функциональность и соотношение цена / качество, выбраны следующие решения, которые позволили бы с помощью минимального количества программных продуктов создать гибкую, полноценную и универсальную систему управления агробизнесом с возможностью конфигурировать ее в зависимости от изменения потребностей. Предлагается дополнительно обратить внимание разработчиков на то, что по каждому направлению необходимо разработать программный продукт, нацеленный на развитие, в широком смысле производственного и макроэкономического общественного явления, с помощью которого можно не просто управлять земельным банком, а земельным развитием. Программы должны формировать геоинформационную характеристику пространственного базиса в разрезе, по правовому статусу и по правосубьектам. Доказано, что внедрение современных технологий повышает контроль активов компаний, прозрачность процессов и информационное обеспечение менеджмента, снижает риски ведения бизнеса.

Ключевые слова: информационные системы, агропроизводства, управленческие решения, земельные ресурсы. 